\title{
ARQUIVOS DO CINEMA XAVANTE: LEGENDAGEM E PRÉ-EDIÇÃO
}

\author{
AUTOR: NICOLLE OLIVEIRA NASCIMENTO DELA CRUZ \\ CO-AUTOR/ORIENTADOR: BERNARD PEGO BELISARIO
}

Resumo: Esta pesquisa, com o cinema e com o cineasta Divino Tserewahú, realizador indígena formado pelo projeto Vídeo nas Aldeias, acompanha seu processo de retomada das imagens e da filmagem do ritual de iniciação (espiritual) Waia Rini na aldeia Xavante de Sangradouro (MT); e de retomada dos próprios filmes, que passam a ser "desmanchados" de modo a acolher novas perspectivas, compartilhadas com os anciãos e com a sua comunidade, mas também com os espectadores "waradzu" (não indígenas). O plano de trabalho consiste em realizar a revisão do mapeamento, feito no primeiro ano de pesquisa, das imagens históricas do Wai'a Rini $(1987 ; 2000 ; 2015)$, editar, formatar e aplicar a legendagem nos vídeos das entrevistas em língua Xavante, organizar uma pré-edição de sequências temáticas do ritual, preparar a apresentação para o congresso de Pesquisa, Criação e Inovação da UFSB e construir um portifólio para o cineasta Divino Tserewahú, com sua biografia e obras.

Palavras-chave: Cinema Xavante, Documentário, Xavante. 